\title{
Genetically altered tomato set to get the green light
}

Herndon, Virginia \& San Francisco. A rotresistant, vine-ripened tomato seems likely to become the first genetically engineered food to go on direct sale in the United States, after an advisory committee to the US Food and Drug Administration (FDA) concluded at a public meeting last week that there are no outstanding safety issues to be resolved.

The conclusion has been widely welcomed in the biotechnology industry as a valuable boost to public confidence in genetically engineered products, particularly after the controversy surrounding the introduction in February of Monsanto's genetically engineered bovine growth hormone, BST.

As a result, the tomato, produced by Calgene of Davis, California and due to be sold under the brand name Flavr Savr, could be in grocery stores by summer. But some critics are still arguing that final clearance should be withheld until outstanding questions concerning issues such as pre-market notification, labelling and concern about allergenicity (the potential for causing an allergic reaction) are resolved.

The three-day meeting was held at the request ofFDA Commissioner David Kessler to determine whether the process already used by the agency to evaluate the safety of new whole foods such as the Flavr Savr tomato was adequate.

Calgene was not required to ask for approval from regulators, as the FDA decided in May 1992 that foods developed through biotechnology are not inherently dangerous

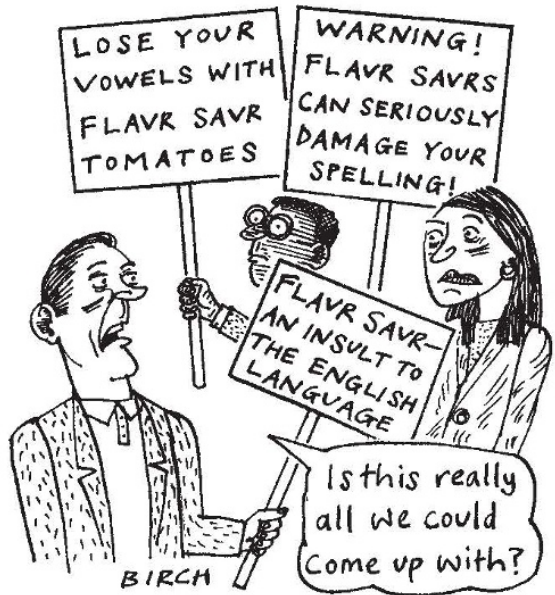

and will not normally require pre-market approval unless they contain substances new to the food supply or known allergens.

But the company had requested a safety review in order to meet potential criticism from consumers. Its new tomato has been modified to suppress the production of an enzyme that causes it to go soft, giving producers more time to let tomatoes ripen on the vine before being picked.
Last week's meeting was held less to meet a specific regulatory requirement than to address public confidence in genetically engineered products. As such, John Bedbrook, executive president of DNA Plant Technology (DNAP), based in New Jersey, says it is likely to prove "pivotal" for the agricultural biotechnology industry.

The Foundation on Economic Trends, an activist group based in Washington that has consistently opposed genetic engineering, has already threatened to organize a boycott of the Flavr Savr tomato.

But most committee members felt comfortable about approving the tomato for sale. Gustaaf de Zoeten, for example, professor of plant pathology at Michigan State University, said he was satisfied that all the necessary safety considerations had been addressed. Arguing against any additional delays - it had been about 5 years since Calgene first undertook field testing of its Flavr Savr tomato - de Zoeten said the company should not be held hostage until the more general questions are resolved.

At the same time, a few of the advisory committee members - and several of the public participants in the meeting - expressed concern at the failure of last week's meeting to address on some of the broader issues involved.

Jane Rissler, staff scientist at the Union of Concerned Scientists, said that FDA should respond to the thousands of negative comments on its biotechnology food policy before approving any genetically engineered whole food. To do otherwise, she said, would be "premature".

Others noted that, while Calgene was willing voluntarily to submit safety and environmental data on its Flavr Savr tomato to intense public scrutiny, other companies may be less cooperative. Calgene also plans voluntarily to label its product. Indeed DNAP, which expects to enter the market early next year with its own genetically engineered tomato, says it has no plans to submit its product to the FDA for scrutiny or to label it in any special way.

The use of antibiotic resistance genes as selectable markers - the kanamycin resistance gene is used in the Flavr Savr tomato was also called into question, particularly in view of the reported build-up of antibiotic resistance.

Whether the agency will require some form of pre-market notification is "under active consideration", said Kessler. At least for the time being, the FDA is likely to implement a policy requiring growers and manufacturers to notify the agency of their intention to sell genetically engineered foods.

Diane Gershon and Sally Lehrman

\section{Columbia aims to raise $\$ 100 \mathrm{~m}$ a year from new ventures}

Washington. Columbia University, which earns $\$ 31$ million a year from licences based on research carried out by faculty members, more than any other US university, plans to use some of this income to fund a new venture to encourage close collaboration between its staff and industrial partners.

The Columbia Innovation Enterprise (CIE), to be launched in July, is a "bridging organization" to take ideas originating in the university and adapt them to industrial use, according to Michael Crow, the viceprovost. Through a strategy of "innovation enhancement", CIE will help Columbia researchers to modify products developed in the laboratory, from software to biological cells, and make them "more palatable for outside consumption", says Crow.

The university plans to publicize the availability of these and other research products through a computerized information service. According to Crow, CIE will engage in a "conscious, planned effort" to develop new commercial enterprises in such areas as biotechnology and manufacturing.

In addition, the university plans to establish a new network using telecommunications to allow companies all over the world to work with Columbia researchers. The purpose of this network, says Crow, is to move away from isolated, ad hoc associations. The university will test a pilot version of the network next year in Asia and the United States, and hopes to have an operational network early in 1996.

CIE will respect the same conflict-ofinterest rules covering faculty-industry cooperation as those observed by its predecessor, Columbia's Office of Science and Technology Development. Faculty members will not be allowed to hold equity positions in companies for which they are doing research, and only "minor delays" to protect proprietary information will be allowed when publishing research results.

Although most royalty rights are retained by the inventor or discoverer at Columbia, some 140 licences are held by the university itself. In such cases, 25 per cent of the royalties go to the individual who carried out the research, 25 per cent to the university, and the rest is split between the department or research group and the body which sponsored the original work.

This year Columbia will earn $\$ 31$ million in licensing fees, based on product sales worth $\$ 2.8$ billion from inventions and discoveries made at the university. This puts Columbia alongside Stanford University as the top two money-makers in this area. Crow says that CIE's goal is to generate an income of $\$ 100$ million a year after nine years.

Tony Reichhardt 